\title{
Н.П. Погодаев
}

\section{ОСИЁВИ, ХАМЧУН РУСИ НАВИН: ОБРАЗОВАТЕЛЬНАЯ МИГРАЦИЯ ИЗ ТАДЖИКИСТАНА В РОССИЮ КАК РЕСУРС ФОРМИРОВАНИЯ ТРАНСГРАНИЧНОГО ОБЩЕСТВА}

\begin{abstract}
Исследуется попытка руководства двух стран преодолеть противоречие между ухудшением качества образования в Таджикистане и возросшими требованиями к уровню подготовки таджикской молодежи, поступающей в российские университетыл, с помощью рекрутинга российских учителей для работы в иколах Таджикистана. Рассматривается вопрос о том, что, окончив университеты, часть таджикской молодежи останется в России, формируя слой «новых русских азиатов», являюшихся активными субъектами различных сфер жизни обеих стран. В качестве методологической основы используются работы П. Бурдьё, в качестве эмпирической основы материаль индивидуальных глубинных интервью со студентами-таджиками и руководителями таджикских диаспор городов Сибири.

Ключевые слова: трансграничное общество, образовательная миграция, Россия, Таджикистан, новые русские азиаты, культурный капитал, символический капитал.
\end{abstract}

Феномен массовой миграции из стран Центральной Азии в Россию ставит нас перед необходимостью осмысления перспектив этого процесса. Трудовая и образовательная миграция обеспечивает соединение территориально распределенных средств производства с рабочей силой и территориально распределенных образовательных ресурсов с теми, кто стремится к получению качественного образования. Эти процессы, имея массовый и пролонгированный характер, не просто оказывают существенное влияние на отдающее и принимающее общества, но и порождают качественно новые явления социальной реальности. Так институализированные миграционные потоки из Таджикистана в Россию ведут к формированию трансграничного общества ${ }^{1}$. Последнее возникает не просто в процессе взаимодействия двух стран, а в процессе «разделения» индивидом себя между homeland и hostland - страной происхождения и страной проживания. Родина все еще живет во многих культурных стереотипах и ностальгических воспоминаниях индивида, а принимающая страна требует больших усилий для интеграции в новое общество [1. C. 79].

\section{Сармоя аз Донишгоххои Русия / Капитал от российской}

\section{Alma Mater}

Активными агентами трансграничного общества являются студенты из Таджикистана, оканчивающие российские вузы. Выпускники университетов претендуют на обладание не только культурным капиталом в виде знаний, но и символическим капиталом в виде дипломов. Понятие «символический

${ }^{1}$ То же самое, конечно, можно сказать и по поводу взаимодействия России с Узбекистаном и Киргизией. 
капитал», введенное в социологический тезаурус французским социологом Пьером Бурдьё, позволяет выделить внеэкономическую составляющую взаимодействия индивидов и социальных групп. Объяснению этого понятия посвящен одноименный раздел в его работе «Практический смысл» [2. С. 96104]. Анализируя феномен символического капитала на примере отношений среди крестьян в различных сферах жизнедеятельности - от возделывания земли и покупки скота до заключения браков, Бурдьё показывает, как эта внеэкономическая составляющая не только облегчает процессы социального обмена, но и ведет к приращению материального капитала. «Материальный капитал конвертируется в капитал символический, - пишет он, - а тот, в свою очередь, подлежит конвертации в капитал материальный» [Там же. С. 101]. Критикуя «экономизм», Бурдьё анализирует общественные отношения с точки зрения «социальной физики», которая, подобно физике как таковой, раскрывает механизмы, лежащие в основе жизни общества. Символический капитал создается немалыми усилиями индивида или социальной группы для того, чтобы в дальнейшем увеличивать уже не символический, а вполне реальный финансовый или экономический ресурс агента. «Зная, что символический капитал - это кредит, но только в самом широком значении слова, т.е. своего рода аванс, задаток, ссуда, которые одна лишь вера всей группы может предоставить давшему ей материально-символические гарантии, легко понять, что демонстрация символического капитала (всегда весьма дорогостоящая в экономическом плане) составляет, вероятно повсеместно, один из механизмов, благодаря которым капитал идет к капиталу» [Там же. С. 102].

Понятие «символического капитала» в качестве аналитического инструмента используется П. Бурдьё и в других его работах. Так в «Социологии социального пространства» автор пишет, что «логика официальной номинации видна как никогда хорошо на примере звания - дворянского, ученого, профессионального, т.е. символического капитала, гарантированного юридически... Профессиональное или ученое звание - это определенного рода юридическое правило социальной перцепции, воспринимаемое бытие, гарантированное как право. Это институционализированный и законный (а не просто легитимный) символический капитал, все более и более неотделимый от ученого звания, поскольку система образования стремится все более и более предоставлять дальнейшие и верные гарантии для всех профессиональных званий. Символический капитал обладает также самоценностью... получая всю возможную символическую прибыль (и блага, которые не продаются за деньги)» [3. С. 30]. Трансграничное общество в процессе своего развития и функционирования также с неизбежностью включает «символический капитал» в круг своих ресурсов. Университетские дипломы, получаемые выходцами из Таджикистана в России, являются одной из его разновидностей.

\section{Хати монеа дар фазои забонй ва хосиятхои масофаи фархангй / Полоса препятствий в языковом пространстве и оптика культурной дистанции}

По данным Минобрнауки, в 2014 г. в российских вузах учились 8777 студентов из Таджикистана, в 2015 - 11731 [10]. В 2016 г., по словам российского посла в Таджикистане Игоря Лякина-Фролова, в российских университетах учились более 20 тыс. выходцев из Таджикистана [14]. Выбор студентов 
объясняется тем, что в обмен на затрачиваемые ресурсы (материальные, физические, моральные) они хотят получить диплом, который гарантирует им более качественные знания и обеспечит более высокие позиции на рынке труда, нежели диплом таджикского университета. Но путь к обретению этого символического ресурса тернист. Об этом свидетельствуют материалы интервью с таджикскими студентами, которые учились и учатся в университетах Томска и других городов Сибири.

Материалы интервью цитируются с сохранением лексических и грамматических особенностей речи респондентов. Особенности речи в ряде случаев выделены в тексте жирным шрифтом и подчеркиванием. Это дает возможность показать и степень владения русским языком, и те трудности, с которыми сталкиваются в языковом пространстве и молодежь, недавно приехавшая на учебу в Россию, и те, кто живет здесь давно.

«Так как у нас преподавателев... на русском языке мало кто преподает сейчас. Так как они уехали. Вот. Приехали в Россию, чтобы тоже зарабатывать, так как там (в Таджикистане. - Н.П.) зарплаты маленькие. Поэтому... можно сказать, что не по профессии они преподают, люди, которые просто, ну знают немножко русский язык, они преподают. Поэтому я плохо училась в школе, но, как бы... оченка отличная, но на самом деле я плохо знала русский язык. Я понимала, но... трудно было разговаривать, и сказать свои там... рассказать что-то, если хотела. Вот. А приехала в Россию, и среди русских живу, и начала разговаривать» [17]. «...тут высококвалифицированные преподаватели, очень хорошие. Вот. Вот из-за этого, мне кажется. Специиалистов тут много (больше. - Н.П.), чем у нас, у нас там маловато. Ну, по моему мнению» [16]. Не скрывали студенты в интервью и некоторых особенностей организации учебного процесса у себя на родине: «Ну, разница в том, что... там берут взятки! Они требуют прямо! А здесь требуют знания! Вот. Поэтому мне не нравилось там учиться» [17].

Банком символического капитала в виде дипломов выступает государство [3. С. 240-241]. Именно ему принадлежит право контроля качества обучения. Качество владения иностранцами русским языком в России определяется утвержденными государством тестами [11]. Процесс освоения русского языка как ключевого условия получения выходцами из Центральной Азии образования в России лежит в лоне систем образования обеих стран: их размежевания в условиях постсоветского развития и поиска путей нового взаимодействия. Представление о трудностях изучения русского языка таджиками дает нарративное интервью с магистрантом, приехавшим из Таджикистана в один из томских университетов для совершенствования владения русским языком [19]. Этот предмет он начал изучать в таджикской школе в конце 1990-х гг., когда там уже не было ни одного носителя русского языка. Несмотря на это, окончив школу, молодой человек решил стать преподавателем русского языка и с этой целью поступил на факультет русского языка и литературы в один из провинциальных университетов Таджикистана. Там среди преподавателей тоже не было русских. Только, говорит респондент, «когда мы были в четыре курс... на четвертом курсе, ну была одна, да, русская женщина. Но у нее профессия, ну, можно сказать только училище. Образование у нее... - не высшее образование... Вела премет (предмет. - Н.П.) по фразеологизм... ещче методика преподавания русского языка... Из-за не- 
хватка кадров, тем более русские... с кафедру русского языка и литературы может ее принил».

Преподавание в вузе велось в основном на русском языке. Исключение составляли лишь предметы, касавшиеся непосредственно Таджикистана: история страны и родной язык. Из 25 студентов группы до выпуска дошли 18. По завершении бакалавриата мой собеседник и его сокурсники не писали выпускную квалификационную работу, а лишь сдавали госэкзамены по педагогике, психологии, русскому языку и русской литературе. По оценке самого респондента, уровень знания русского языка после окончания бакалавриата в таджикском университете был невысок: «Когда я закончил я не очень хорошо учил русский язык, да, владел русский язык - то, что я хотел» (так, как я бы хотел. - Н.П.). После университета работал учителем: «...работал в школе три года. Обично я работал там в младиих школе сначала, потом в висшим... эээ... стариим. В школе два ставка было у меня: первий - русский язык я преподавал, и второй у меня этот... как можно сказать, заместитель директора по часть обучать... - да, завуч».

Человек, проработавший три года не только учителем, но и завучем в провинциальной таджикской школе, конечно же, хорошо знает систему преподавания там русского языка: «Обично завуч составляет всю программу в школе. Я могу сказать - русский язык, как второй язык в Таджикистане, в нэдэли три раза преподается в школе... со второго класса начинается... по одиннадиатый, как второй государственный язык». Более того, говорит респондент, преподавание русского языка улучшается: «Количество часы они допольняют ... собраются... допольнить это количество часы, во-первих, вовторих... они хотят создать... параллельные группь - именно русские групnығ... Мы создали, в том числе, „Дэн русского языка“... в этот ден мы польно говорим по-русски - преподаватели, ученики, все». Работа завучем была связана с организацией учебного процесса на родном языке, что у моего собеседника, по его словам, хорошо получалось. Он очень быстро получил звание учителя первой категории. Но для освоения русского языка решил ехать в Россию: «...причина в том, что у меня проблема с русским языком. Я хочу узнать и овладеть русский язык и совершенствоваться в его знании... Для меня трудно это, действительно трудно... Но возврат нече (возврата нет. - Н.П.)». Появилась возможность сравнить содержание подготовки по русскому языку на родине и в России: «Ну, обично то, что мы там учили, здесь нет... Те предметы, которые я здесь училь, там не было. Лингвокультурология, ну, риторика. У меня не было никаких информаций об етим... И риторика здесь и культура речи тоже здесь... Никаких из них там я не учил... там элементарные вещи, можно сказать, в бакалавриате учатся... А здесь, ну, боле сложное... То, что мы учили дополнительно занятий, то есть русский язык для иностранцев... мне нравится это... Программа очень прекрасна, но жаль, что эта была мала». То есть больше всего ему понравился курс по русскому языку как иностранному. Это именно то, говорит, что его интересует: «То, что я хотел в Таджикистана, видел на этом программа было (в программе РКИ. - Н.П.). ...Падежи изучили, рассказ, ну, как можно рассказать - развитие речи, ну, части речИ, изУчили части речи».

Парадоксальным выглядит его признание по поводу затруднений в освоении разговорной лексики в Томске: «Потому что ми не разговариваем по- 
русски - здесь даже. Когда есть занятия, ну толко в занятии. Магистерский занятий, ну, мало... в неделю два дня - некоторые три пара, некоторые два». Его огорчает отсутствие возможности совершенствовать язык, живя с его носителями в одной комнате: «В общежитии вместе с таджики - вместе живем... У меня не письменный заявление, но устный заявление было у меня, когда я приехал сюда, заведующей общежития, что нас заселяй, пожалуйста, с русскими, чтобы ми... эээ... ми приехали сюда учить русский язык. Но, к сожалению, я... не знаю почему нас не заселил с русским - все таджики или, ну, иногда туркмены или узбеки... Я против этого. Я даже в деканате этого сказал, что ви не прав. Мы приехали учить русский язык в русской пространстве. Но обично ви создавали нас таджикский пространство». Ряд обстоятельств, как говорит, препятствует и тому, чтобы общаться с русскими вне стен кампуса: «У нас нет времени, чтобы с ним говорить или с ним пойти куда-нибудь. Русские обычно всегда гуляют, а у нас нет (времени. - Н.П.). Если мы пойти на прогулка или чё типа того, на другие месте или что, или с ним играть в какой-то игры с русским, ну у нас занятия, надо готовиться к занятий - сдать все, экзамен или зачет... Мы пишем свою научную работу, какой-то задание, другие задачи».

Оптика трансграничного пространства рассматривает обучение в университете не только как систему передачи знаний, но и как коммуникацию между студентами и преподавателями, выделяя особенности педагогических паттернов двух культур. В томском университете, говорит респондент, «...удивил толко отношение преподавателей со студенти, все... Их отношение со студентом - не только с иностранцем, но и с родным студентом очень отличные, можно сказать. Близкие отночения, они питаются, чтобь действительно виполнять они свои профессии, педагогические задачи. Они тиательно работают со студентом». В отличие от таджикского университета, где «студент не свободно сможет задать свои вопросы преподавателю... У них нет близкий отношений с преподавателем... Статус преподавателя совсем в другом части, а студента - в другом. (А в Томске. - Н.П.) студен свободный, он то, что хочет сказать и задать вопрос, то, что хочет спросить у преподавателя свободно - сможет спросить». Более жесткая регламентация внутриуниверситетской жизни таджикских вузов проявляется, говорит, в существовании обязательной формы для юношей: темный костюм с галстуком и белая рубашка. Для девушек форму ввели позже, но теперь есть определенные требования по одежде и для них.

Среди деталей повседневного быта отмечает то, в чем ходят студентки в томском общежитии, чем это отличается от Таджикистана: «...здесь абсолютно по-другому. Ну, они обично... ну, как сказать... (долгая пауза) ну, белье... как можно сказать... (снова долгая пауза) об этим мне трудно будет сказать... они ходят в общежитии более неодетье, можно сказать, а у нас одетые». Но это как элемент свободы в целом, которую он не раз отмечал в ходе разговора: «Свобода слов, свобода применения одежды, свобода учеба, конечно. В общем, везде можно встретить свободу... Студент или человек может... или имеет право выразить свое мнение». Иную природу отношений в Таджикистане объясняет тем, что «с точки зрения культура нас так воспитывают, во-первих... есть такое выражение „Пред взрослими людьми младших нельзя говорить“. Так нас воспитывают. А потом - у нас нет сво- 
бодный пресс, свободное слово, когда мы говорим, в одну сторону (с одной стороны. - Н.П.). В другой - закон у нас не позволяет, чтоб мы будем свободны. A тот, кто питается говорить свободно (здесь респондент даже рассмеялся) конечно, ясно что будет - ответит перед законом, ответит перед сотрудником... ну, как можно сказать... касающий орган, перед касающиий орган (перед карающими органами. - Н.П.)».

Есть и строгий регламент по поводу использования сотовых телефонов в университете: «...использовАние мобильный телефон у нас абсолютно запрещено... если во время занятия ви используете телефон - разговор ... ну, первий раз... объяснение от вас требуют, а второй раз, все, автоматически исключают».

\section{Темпорально-топологические характеристики символического капитала}

Диплом российского университета может иметь разный вес в пространствах отдающего и принимающего обществ. В России выходец из Таджикистана, получивший диплом российского университета, конкурирует на рынке труда с российскими носителями этого символического капитала. Результаты этой конкуренции неоднозначны: талантливый потомок персов и саманидов вполне может ее и выиграть. Но ему, вероятно, придется приложить больше усилий для доказательства своих профессиональных компетенций, так как на первых порах его background может уступать позициям коренных представителей принимающего общества. Об этом в интервью рассказывал один из руководителей таджикской диаспоры в Красноярске, окончивший российский вуз: «...здесь, вот, в нашем крае вот такая проблема, что иностранные студенты, которые заканчивают, сложно их... эээээээ... по поводу... ээээ... в дальнейшем работать здесь. Потому что не берут таких, не каждого берут, и не каждый может по профессии работать... Это очень большая головной бол для нас тоже, для молодежь, потому что мы сколько лет учились здесь, заканчивали, да, мы не можем здесь по диплому работать уже» [20]. Примерно о тех же проблемах говорит и респондент из Томска: «У меня племянник закончил (называет один из томских университетов. - Н.П.)... И в ходе практики он работал на одной предприятии по сборку... э... плат в Академгородке. И там, в принципе, постепенно он стал успешным... Bот... а ему хотелось... не остановиться на достигнутом... Ну, и находит другую работу, там испытательный срок. На испьтательном сроке он показывает себя... достаточно хорошо. А... напарник отстает от него... и в результате потом руководитель говорит, что ты не прошел испытательный срока, мы, мол, тебя не берем. А была причина именно в зависти и то, что он нерусский, а хотя он хороший специалист» [21]. Подобную ситуацию подтверждают и представители административных структур принимающего общества: «В ИТР им попасть очень сложно - в категорию ИТР - инженернотехнических работников. Потому что у нас есть свой, что называется, здесь контингент и работодатель, вот опять-таки... ну есть же какие-то там предрассудки, наверное, определеннье, традиции уже. Ну, наверное, он предпочтительно возьмет местного - именно из соображений предсказуемости. Не из фашистских каких-то там или шовинистических этих, а вот предсказуемости» [12]. 
Что касается отдающего общества, то на том поле таджики-выпускники российских университетов конкурируют с обладателями дипломов таджикских вузов: «А на родине российский диплом очень такие авторитетныле и везде все берут их на работе» [20]. «...в прошлом году я прочитал объявление в мерии в самом Душанбе. Мерия принимает... подала объявление... принимает на работу молодежь... выпускников российских вузов» [21]. Очевидно, распространенность подобной точки зрения в общественном мнении Таджикистана и является одним из основных стимулов таджикской молодежи ехать на учебу в Россию.

Символический капитал российского диплома, полученного выходцем из Таджикистана, может рассматриваться с темпорально-топологической точки зрения. С темпоральной (временной) точки зрения речь идет о том, что значение диплома имеет вполне реальный шанс сохраняться на протяжении всей жизни индивида. «Звание само по себе, - пишет Бурдьё, - институция более прочная, чем внутренние характеристики труда. Вознаграждение за звание может сохраняться, несмотря на изменения в труде и его относительной ценности: не относительная ценность труда определяет ценность имени, но институционализированная ценность звания служит средством, позволяющим защитить и сохранить ценность труда» [3. С. 31]. Для таджиков в России пролонгированный характер символического капитала - диплома российского университета - связан с тем, что номинация «выпускника российского университета» легитимизирует дальнейшее пребывание в России, выход на российский рынок труда и процесс дальнейшей социализации в принимающем обществе. Последнее связано с вхождением в более высокие социальнопрофессиональные слои «специалистов с высшим образованием» и возможностями последующей карьеры. С топологической точки зрения (с точки зрения места обучения) диплом российского университета означает, в частности, знакомство индивида с условиями того региона России, где он учился, с культурой местного населения, с условиями на местном рынке труда, включенность в местную национальную диаспору и т.п. Важно не просто знание языка, но и тех культурных локаций, где происходит его изучение.

\section{Don't put all your eggs in one basket}

«Диверсификация» языковой сферы Таджикистана является ответом на вызов экономической отсталости страны. Одним из способов ее преодоления является развитие контактов с более развитыми государствами. Взаимодействие с Россией не является единственным направлением. Несмотря на большую культурную и экономическую дистанцию с передовыми странами англоязычного мира, в Таджикистане закладываются основы программы подготовки специалистов с университетским образованием на английском языке. Ее организатором является духовный лидер памирских исмаилитовнизаритов принц Карим Ага-Хан IV. В Хороге - центре Горно-Бадахшанской автономной области - он строит Университет Центральной Азии, о котором студенты-таджики говорят с надеждой и пиететом: «Сейчас наш духовнылй руководитель открывает Университет Центральной Азии. В Казахстане открылась, в Кыргызстане - в Бишкеке и вот в этом году или в следующем в Хороге» (интервью проводилось в мае 2017 г. - Н.П.) [18]. Преподавание на английском языке объясняется и тем, что это создаст возможность продол- 
жать образование в англоязычных странах, и тем, что учиться в университете Ага-Хана смогут исмаилиты из целого ряда государств. Известно, что Горный Бадахшан поделен между Таджикистаном и Афганистаном, а общины исмаилитов существуют более чем в двух десятках стран. Но, несмотря на этот англоязычный проект, так или иначе ориентированный на развитие коммуникаций с развитыми странами Запада, Ага-Хан поддерживает и активные связи с Россией - и на уровне существующих здесь общин мигрантов, и на уровне российского истеблишмента. На встрече с министром иностранных дел России Сергеем Лавровым в апреле 2017 г. в Москве Карим Ага-Хан сказал, что встреча очень важна для него, так как «...сотрудничество с Россией является критически важным не только для моего сообщества, но и для всей Центральной Азии, где мы сейчас создаем совместные институты, которые будут иметь большое значение для региона» [13].

В Москве Ага-Хан поддерживает таджиков-исмаилитов, создавших Региональную общественную организацию «Нур». Там, в частности, учат и русскому языку, говорит респондентка: «Это как школа... они договариваются с определенными компаниями, с определенными школами, с преподавателями... Наш офис трехэтажный... там как раз расположены наши офисы все... по разным вопросам - кто отвечает за учебу, кто-то за спорт... и часть - процентов семьдесят оплачивает Фонд (Представительство «Фонда Ага-Хана» в Российской Федерации. - Н.П.), процентов тридиать... - родители. А потом, если дети у них достижения лучше, они с уровня на уровень проходят и каждый уровень на 10 прочентов меньще и в итоге это становится вообще бесплатно... У нас теперь открылась такая же большая цеентр в Екатеринбурге» [18].

\section{Муаллими Рус, хамчун супориши махсус ва захираи чомеаи байнисархадй / Русский учитель как миссия и ресурс трансграничного общества}

Увеличение численности таджикских мигрантов в России ведет и к расширению дипломатических структур Таджикистана в РФ. Помимо посольства в Москве, по данным на 2017 г., в России существует еще 4 Генеральных консульства Таджикистана. Первое из них - в Екатеринбурге - было открыто в 2009 г. В 2011 г. - в Уфе. Его создание связывалось с открытием Генерального консульства России в столице Согдийской области Таджикистана Худжанде. Сразу два - в Санкт-Петербурге и Новосибирске - были открыты в 2017 г. Как правило, создание этих дипломатических представительств объяснялось наличием большого количества таджиков, которые живут на территории соответствующих федеральных округов России, проблемами, с которыми они сталкиваются при оформлении необходимых документов и патентов на право работы. По разным данным, на территории России в 2017 г. проживали от 600 тысяч до миллиона таджиков.

В то же самое время в последние годы ряд российских университетов стал отказываться от приема абитуриентов из Таджикистана. Причиной этого стало не только слабое знание русского языка, но и слабая подготовка по базовым предметам: «Тенденция, к сожалению, ухудшается, - говорит представитель приемной комиссии одного из томских университетов, - из Таджикистана мы уже почти не набираем. В основном это произвольный самоток, 
который идет, так скажем, через Россотрудничество, либо через какие-то знакомые связи - может друг сюда приехал, родственники приехали, вот, и они их перетягивают. Что касается наших выездов туда, ээээ... ну опять же говорю, знание русского языка оставляет желать лучшего» [15]. Возникли два противоположных тренда: понижение качества преподавания русского языка и других базовых предметов в Таджикистане и повышение требований к уровню знаний в отношении таджиков, с теми или иными целями въезжающих в Россию. Объективация этих проблем привела к формированию соответствующих рефлексий на межгосударственном уровне. Посетив с официальным визитом Таджикистан в октябре 2016 г., Председатель Совета Федерации Валентина Матвиенко заявила, что Россия поможет с улучшением изучения русского языка в Таджикистане [8]. Визит Президента России Владимира Путина в страну в феврале 2017 г. добавил динамики решению этой проблемы [4]. К началу 2017/2018 учебного года в Таджикистан выехали около трех десятков учителей русского языка, математики, информатики, физики, химии и биологии. Вероятно, что при отборе первой группы учителей использовалась определенная тактика. Обращает на себя внимание то, что среди участников этого пилотного проекта нет учителей из российских столиц - Москвы и Петербурга. Российская провинция представлена Кемеровской и Костромской областями, а также тремя республиками с преимущественно мусульманским населением - Татарстаном, Башкортостаном и Дагестаном. Поездка учителей из Дагестана связана, очевидно, еще и с тем, что в то время главой республики был Рамазан Абдулатипов, с 2005 по 2009 г. занимавший должность чрезвычайного и полномочного посла России в Таджикистане. Есть среди группы учителей и русские уроженцы Таджикистана, некогда покинувшие эту страну. Педагогический стаж учителя должен составлять не менее пяти лет. Изначально российским специалистам предлагается работать в таджикских школах в течение одного года, но при желании контракт может быть продлен. Причем учителя из России будут не только вести уроки, но и «оказывать методическую поддержку местным учителям». Вернувшись в Россию, педагог сможет занять свое прежнее рабочее место. С учебниками помогает проект «Русский мир». Учителям обещана высокая зарплата: 14 тыс. рублей за счет бюджета Таджикистана и 60 тыс. - из бюджета России. Она же предоставляет и медицинскую страховку. Жилье учителям обеспечивает Таджикистан. Он же оплачивает перелет педагогов. Оплата труда педагогов вызвала определенную рефлексию в обеих странах, где зарплаты учителей за работу на родине гораздо ниже [9].

То, что в Таджикистан поехали учителя из ряда российских регионов с преимущественно мусульманским населением, возможно, не случайно. Это ресурс усиления, вероятно, не только образования как такового, но и традиционного ислама в противовес попыткам определенных кругов Таджикистана формировать у тамошних школьников приверженность к радикальным течениям данной религии. Таким образом, транзиту религиозных идей из пространства, так или иначе связанного с идеей исламского халифата, могут быть противопоставлены гораздо более умеренные течения ислама, не противоречащие функционированию этой религии в условиях сложившихся национально-государственных образований [7]. Если пилотный проект будет удачным, то количество учителей из России в Таджикистан, возможно, будет 
увеличиваться. Например, в пресс-релизе администрации Томской области по поводу встречи губернатора Сергея Жвачкина с генеральным консулом Таджикистана в Новосибирске Зарди Шамсиддином Курбонзода говорится, что на фоне иных проблем возможного взаимодействия они «отдельно обсудили сотрудничество в научно-образовательной сфере». В материале обращается внимание на причины, препятствующие приему студентов из Таджикистана в университеты Томска: «Сегодня в томских университетах учатся 240 студентов из Таджикистана. Это немного, и преградой для резкого увеличения численности таджикских студентов является языковой барьер. Мы готовы направить в вашу республику преподавателей русского языка, чтобы они готовили школьников к поступлению в наши университеты», - сказал губернатор Сергей Жвачкин [22]. Позиция губернатора в этой ситуации отражает, видимо, консолидированное мнение руководства томских университетов по поводу качества знаний молодежи, приезжавшей из Таджикистана в минувшие годы. Планы, о которых заявляет руководство России, идут еще дальше. В ходе вышеупомянутого визита Президента Владимира Путина было сказано, что Россия построит в Таджикистане 20 общеобразовательных школ, обучение в которых будет вестись на русском языке. Куратором этого проекта является вице-премьер Игорь Шувалов. Он сказал, что «это пока звучит так: это должна быть инвестиция российского государства, школы будет содержать Таджикистан. Но сама материальная инфраструктура будет создаваться за счет бюджетных инвестиций Российской Федерации» [4]. Планируется, что русские школы будут своеобразным пролонгированным проектом. Их статус будет выше обычных таджикских школ, а выпускники получат высокие шансы на продолжение обучения в российских вузах.

\section{Осиёви, хамчун руси навин / Новые русские азиаты}

Закладывая свою относительно зыбкую основу в первом поколении мигрантов, трансграничное общество получит реальное воплощение в последующих поколениях «новых русских азиатов»- интегрированных в российское общество выходцев из Центральной Азии. Институализация этого феномена произойдет через соответствующие «стратегии воспроизводства», о которых говорит П. Бурдьё [3. С. 102]. Среди них - стратегия матримониального и репродуктивного поведения, а также образовательные стратегии. К особенностям матримониального поведения можно отнести смешанные браки части мужчин-таджиков с представительницами иных этносов из состава принимающего общества. Прежде всего это может касаться тех, кто, окончив российские университеты, решит остаться в России. Выход из-под контроля семьи в Таджикистане, общение в российской молодежной среде усиливают усвоение паттернов принимающего общества, что может привести к межнациональным бракам. А эти последние станут механизмом дальнейшего усвоения паттернов местной культуры. К их числу, возможно, будут относиться занятость женщин не в сфере домашнего хозяйства, а в сфере наемного труда, относительная малодетность семьи, увеличивающиеся вложения в формирование человеческого капитала детей. Именно этим качеством, a не количеством детей будет характеризоваться сила семейной группы. В последующих поколениях воспроизводство трансграничного общества окажется под влиянием детерминант демографического перехода, описанно- 
го в работах А.Г. Вишневского [5]. Деликатной проблемой по-прежнему будет религиозная принадлежность членов семьи: необходимость и возможность принятия ислама женой, принадлежавшей ранее к одной из христианских конфессий или просто выросшей в условиях христианской культуры. Потомки нынешних выходцев из Центральной Азии в рамках механизма межпоколенческой трансмиссии будут наследовать воспринимаемый от старших поколений вариант культуры общества исхода и отсорбированные ими паттерны принимающего общества. Все это приведет к формированию особого габитуса семей, характерного для трансграничного общества. Образовательные стратегии новых русских азиатов будут направлены, если отталкиваться от методологии Бурдьё, «...на производство социальных агентов, достойных и способных наследовать свойства группы, т.е. передать их, в свою очередь, группе» [3. С. 103]. Критерием отбора этих качеств станет эффективность продвижения к обладанию дефицитными ресурсами общества.

\section{Маълумоти оли барои дигаргуни (ояндаи дурахшон) / Высшее образование для преобразования}

Трансграничное общество с неизбежностью становится частью общества исхода и принимающего общества. В континууме взаимодействия двух вышеупомянутых стран одним из направлений его воздействия на Таджикистан может быть преобразование клановых систем в системы, основанные на бюрократической целесообразности. Методологией подобного подхода служит рассуждение П. Бурдьё о периоде перехода в Англии от «династического государства к бюрократическому», когда велась борьба «между теми, кто не желал знать и признавать ничего, кроме стратегий семейного воспроизводства (братья короля), опиравшихся на кровное родство, и теми, кто прибегал к стратегиям бюрократического воспроизводства (министры короля), основанным на передаче культурного капитала через образовательную систему» [3. С. 107]. Сила клановой системы Таджикистана может постепенно размываться и заменяться более рациональной системой, построенной не на клановой принадлежности, а на профессиональной компетентности. Трансграничное общество, формирующееся в процессе взаимодействия двух культур, может сыграть в этом процессе заметную роль. Транснациональные экономические группировки и профессионалы высокого уровня, окончившие российские и западные университеты, могут стать той бюрократической силой, которая постепенно преодолеет господство клановых группировок. Знания, профессиональные компетенции, в отличие от клановой принадлежности, не могут наследоваться непосредственно и потому становятся механизмом ротации агентов профессиональной сферы деятельности. Изменение положения в экономической сфере через опосредующие механизмы будет постепенно проникать и в сферу политики. Те или иные экономические группировки, основанные на бюрократических началах, а не на клановой принадлежности, будут стремиться получить свое представительство и на политическом уровне. Это путь от возникших на постсоветском пространстве неофеодальных отношений к рыночной бюрократической системе. Процесс подобен тому, что происходило в Европе в период перехода от династического правления к бюрократическому: «На историю европейских обществ оказа- 
ло очень сильное влияние постепенное развитие внутри поля власти способа воспроизводства, основанного на образовании, влияние которого можно наблюдать внутри самого поля власти в виде перехода от династической логики „королевского дома“, опиравшейся на семейный способ воспроизводства, к бюрократической логике государственного интереса (raison d'Etat), в основе которой лежит образовательная модель воспроизводства» [3. С. 112]. Следуя мысли мэтра французской социологии, можно сказать, что диплом хорошего российского университета является для выходцев из Таджикистана «пропуском» в систему трансграничного общества. «Школа (в форме grande école) и корпус - социальная группа, которую школа производит, казалось бы, ex nihilo (но в действительности из характеристик агентов, связанных с семейной принадлежностью), занимают место семьи и родственных отношений. Кооптация однокурсников на основе студенческой солидарности и принадлежности к профессиональному корпусу играет ту же роль, что и кумовство и клановая солидарность на семейных предприятиях» [3. С. 113].

Условием формирования трансграничного общества является не только «разделение» личности между homeland и hostland, как говорилось в начале данной статьи, но и другое качество данного континуума - консолидация индивидов, попавших в трансграничное пространство, в определенные общественные группы. Создание таких корпусов на основе профессиональной солидарности выпускников российских и западных университетов может постепенно преобразовать общество, основанное на клановой консолидации. Обстоятельством, оказывающим косвенное воздействие на движение в данном направлении, может быть вышеупомянутое распределение учителей из России по всем регионам страны - в районы республиканского подчинения, в Хатлонскую и Согдийскую области и даже в Горно-Бадахшанскую автономную область на Памире [6]. Это свидетельствует о том, что запрос на хорошее школьное образование есть во всех регионах страны. Работать учителя из России будут, прежде всего, в «президентских лицеях и школах для одаренных детей». То есть, скорее всего, их учениками будут дети таджикской (в том числе и региональной) элиты. Именно они затем смогут учиться в России и формировать трансграничное общество. В традициях прежних трендов взаимодействия России со странами Центральной Азии и в условиях новых трендов глобализации формирование трансграничного общества будет развиваться ровно настолько, насколько оно будет востребовано перманентными вызовами взаимодействия макрорегионов Северной Евразии и Центральной Азии. Перераспределение ресурсов будет вести к изменению не только социально-экономических, но и этнических реалий. В целом это будет лишь продолжением тех глобальных исторических процессов, которые со времен зарождения человеческой цивилизации шли на пространствах евразийского континента.

\section{Оптика трансграничного}

Таким образом, одним из значимых ресурсов формируемого российскотаджикского трансграничного сообщества является такой внеэкономический ресурс, как культурный и символический капитал, создаваемый в процессе получения таджикской молодежью высшего образования в России. Процесс 
реализуется в рамках противоречивых трендов - понижения качества преподавания русского языка и других базовых предметов в Таджикистане, с одной стороны, и повышения требований к уровню знаний таджиков, намеренных жить в России, - с другой. Крайне слабое преподавание в Таджикистане русского языка, связанное с фактическим отсутствием там русскоязычного населения, усугубляется слабой учебно-методической базой обучения таджиков русскому языку в ряде российских университетов. Проект по набору российских учителей, три десятка которых в 2017 г. впервые поехали работать в Таджикистан, является попыткой преодоления этой ситуации. Неудача данного пилотного начинания грозит дальнейшим ростом препятствий в сфере транскультурных коммуникаций. Активная деятельность в Таджикистане лидера исмаилитов Ага-Хана IV, открывшего в Хороге Университет Центральной Азии и поддерживающего хорошие отношения с Россией, ведет не только к диверсификации языкового и культурного внешнего воздействия на Таджикистан, но и преумножает число таджиков, которые во взаимодействии с Россией смогут использовать английский язык, вливаясь в когорту англоговорящих россиян и расширяя ресурсы трансграничного сообщества. Рост численности таджиков, получивших образование в России, увеличит не только число «новых русских азиатов», обосновавшихся в нашей стране, но число тех, кто, вернувшись в Таджикистан, будет способствовать развитию культуры рационального бюрократического управления, постепенно преодолевающего клановую культуру. Основная функция формирующегося трансграничного общества - повышение эффективности освоения огромных пространств и ресурсов Северной Евразии. Некогда этот процесс получил свое интенсивное развитие за счет массовой миграции в Сибирь ${ }^{1}$ населения из европейской части России. Теперь идет процесс прироста ресурсов Сибири за счет потенциала других соседних регионов. На данном этапе наиболее активное участие в этом процессе занимают страны Центральной Азии. Двуязычие в названиях ряда разделов данной статьи - определенная дань этому процессу. Не исключено, что в названиях статей по поводу трансграничного общества на территории Северной Евразии рано или поздно появятся и китайские иероглифы.

\section{Используемые аббревиатуры:}

ПОВТ - Представитель органов власти Томска и Томской области СПКУ - Сотрудник Приемной комиссии университета

СТТ - Студент таджик из Таджикистана

ТДКр - Руководитель или активный член таджикской диаспоры в Красноярске

ТДТ - Руководитель или активный член таджикской диаспоры в Томской области

\section{Лuтература}

1. Бредников О., Ткач О. Дом для номады // Laboratorium. 2010. № 3. С. 72-95.

2. Бурдьё П. Практический смысл / пер. с фр.: А.Т. Бикбов, К.Д. Вознесенская, С.Н. Зенкин, Н.А. Шматко; отв. ред. пер. и послесл. Н.А. Шматко. СПб. : Алетейя, 2001. 562 с.

3. Бурдьё П. Социология социального пространства : пер. с франц. / отв. ред. перевода Н.А. Шматко. М. : Ин-т экспериментальной социологии ; СПб. : Алетейя, 2007. 288 с.

${ }^{1}$ В данном контексте под Сибирью понимается вся территория России от Урала до Тихого океана. 
4. Визит президента РФ В. Путина в Республику Таджикистан (подборка статей) [Электронный ресурс] // Центральноазиатский портал. URL: http://www.ca-portal.ru/article:33395 (дата обращения: 15.11.2017).

5. Вишневский А.Г. Время демографических перемен : избр. ст. М. : Изд. дом Высшей школы экономики, 2015. 517 с.

6. Гайсина Л. Зачем в Таджикистан приехали российские учителя [Электронный ресурс]. URL: http://www.ca-portal.ru/article:37565 (дата обращения: 15.11.2017).

7. Джерелиевский Б. Русские учителя потеснят в Азии религиозных экстремистов [Электронный ресурс] // Колокол России. URL: http://kolokolrussia.ru/russkiy-mir/russkie-uchitelyapotesnyat-v-azii-religioznh-ekstremistov\#\&hcq=nSkY4Cq (дата обращения: 15.11.2017).

8. Из России с учебниками. Валентина Матвиенко встретилась с учителями, которые отправляются работать в Таджикистан [Электронный ресурс] // Российская газета 28.08.2017. URL: $\quad$ https://rg.ru/2017/08/28/rossijskie-uchitelia-otpraviatsia-v-tadzhikistan-rabotat-v-shkolah.html (дата обращения: 20.10.2017.)

9. Кто едет обучать таджикских детей: знакомство с учителями из регионов РФ [Электронный pecypc]. URL: http://sptnkne.ws/fWP8 Обращение 15.11.2017. (дата обращения 25.10.2017); В Таджикистан приехали первые учителя из России. Они будут зарабатывать по 74 тысячи рублей [Электронный ресурс]. URL: https://www.currenttime.tv/a/28705292.html (дата обращения 15.10.2017); Учителя из РФ поедут преподавать в Таджикистан [Электронный ресурс]. URL: https://www.molbulak.ru/news/tadzhikistan/uchitelya-iz-rf-poedut-prepodavat-v-tadzhikistan/ (дата обращения: 15.11.2017).

10. Министерство образования и науки Российской Федерации. Департамент стратегии, анализа и прогноза [Электронный ресурс]. URL: http://минобрнауки.рф/министерство/статистика/информация-2014 (дата обращения: 3.01.2016); Министерство образования и науки Российской Федерации. Департамент стратегии, анализа и прогноза [Электронный ресурс]. URL: http:/минобрнауки.рф/министерство/статистика/информация-2015 (дата обращения: 16.01.2016).

11. Онлайн тест по русскому языку как иностранному (ТРКИ) [Электронный ресурс]. URL: https://mgu-russian.com/ru/learn/test-online/ (дата обращения: 23.10.2017).

12. ПОВТ-2 - Архив автора.

13. Принц Ага-Хан IV встретился с главой МИД России Сергеем Лавровым [Электронный pecypc]. URL: http://ru.sputnik-tj.com/russia/20170420/1022111837/aga-khan-IV-vstretilsya-ssergeyem-lavrovym.html (дата обращения 20.11.2017).

14. Россия увеличила количество квот для таджикских студентов // Информационное агентство Регнум 7 февраля 2017 г. [Электронный ресурс]. URL: https://regnum.ru/news/2236010.html (дата обращения: 10.11.2017).

15. СПКУ-1 - Архив автора.

16. СТT-6-Архив автора.

17. $С T T-10-$ Архив автора.

18. СTT-15 - Архив автора.

19. СТT-16 - Архив автора.

20. ТДКр-1 - Архив автора.

21. ТДТ-6 - Архив автора.

22. Томский губернатор и генконсул Таджикистана обсудили сотрудничество региона с республикой [Электронный ресурс]. URL: https:/www.tomsk.gov.ru/news/front/view/id/23432 (дата обращения: 25.11.2017.)

Nikolai P. Pogodaev, Tomsk State University (Tomsk, Russian Federation).

E-mail: nick-pogodaev@yandex.ru

Vestnik Tomskogo gosudarstvennogo universiteta. Filosofiya. Sotsiologiya. Politologiya - Tomsk State University Journal of Philosophy, Sociology and Political Science. 2018. 44. pp. 183-198.

DOI: $10.17223 / 1998863 X / 44 / 18$

NEW RUSSIAN ASIANS: STUDENT MIGRATION FROM TAJIKISTAN TO RUSSIA AS A BASIS OF A CROSS-BORDER SOCIETY

Keywords: cross-border society; student migration; Russia; Tajikistan; new Russian Asians; cultural capital; symbolic capital.

The economic and demographic situation in Russia and the countries of Central Asia as well as the interaction between these states throughout the last twenty-five years support a number of trends in 
labour and student migration that have gained sufficient stability. They affect not only the source and receiving societies but also create new social phenomena such as the formation of a cross-border society. This paper aims to analyse the temporal and topological traits of the cultural and symbolic capital of the Tajik youth that study at Russian universities, as well as the possibility for Tajikistan to provide world-class higher education in the English language for future professionals. The author provides a detailed study of the governmental initiatives of both countries that intend to resolve the contradiction between the falling quality of education in Tajikistan and the increasing requirements for entering Russian universities. Since a large number of the Tajik youth aspire to enter Russian universities, teachers from Russia are now invited to work in secondary schools in Tajikistan. In the paper, the author focuses on the situation when after graduation from Russian universities, a part of the Tajik youth stays in Russia, thus helping construct a society of the "new Russian Asians" - active participants in various aspects of life in both Russia and Tajikistan. The methodological basis of this paper is formed by the works of Pierre Bourdieu; the empirical data was collected in the course of individual in-depth interviews with students of Tajik origin and heads of national Tajik diasporas in Siberian cities.

\section{References}

1. Brednikov, O. \& Tkach, O. (2010) Dom dlya nomady [House for nomads]. Laboratorium Laboratorium. Social research journal. 3. pp. 72-95.

2. Bourdieu, P. (2001) Prakticheskiy smysl [Practical Meaning]. Translated from French by A.T. Bikbov, K.D. Voznesenskaya, S.N. Zenkin, N.A. Shmatko. St. Petersburg: Aleteyya.

3. Bourdieu, P. (2007) Sotsiologiya sotsial'nogo prostranstva [Sociology of Social Space]. Translated from French by N.A. Shmatko. Moscow: Institute of Experimental Sociology; St. Petersburg: Aleteyya.

4. Ca-portal.ru. (2017) Vizit prezidenta RF V. Putina v Respubliku Tadzhikistan [Visit of the President of the Russian Federation V. Putin to the Republic of Tajikistan]. [Online] Available from: http://www.ca-portal.ru/article:33395. (Accessed: 15th November 2017).

5. Vishnevskiy, A.G. (2015) Vremya demograficheskikh peremen [Time of Demographic Change]. Moscow: HSE.

6. Gaysina, L. (2017) Zachem v Tadzhikistan priyekhali rossiyskiye uchitelya [Why did Russian teachers come to Tajikistan?]. [Online] Available from: http://www.ca-portal.ru/article:37565. (Accessed: 15th November 2017).

7. Dzhereliyevskiy, B. (2017) Russkiye uchitelya potesnyat v Azii religioznykh ekstremistov [Russian teachers will press religious extremists in Asia]. [Online] Available from: http://kolokolrussia.ru/russkiy-mir/russkie-uchitelya-potesnyat-v-azii-religioznh-

ekstremistov\#\&hcq=nSkY4Cq. (Accessed: 15th November 2017).

8. Mislivskaya, G. \& Novoselova, E. (2017) Iz Rossii s uchebnikami. Valentina Matviyenko vstretilas' s uchitelyami, kotoryye otpravlyayutsya rabotat' v Tadzhikistan [From Russia with textbooks. Valentina Matvienko meets with teachers who will work in Tajikistan]. Rossiyskaya gazeta. 28th August. [Online] Available from: https://rg.ru/2017/08/28/rossijskie-uchitelia-otpraviatsia-vtadzhikistan-rabotat-v-shkolah.html. (Accessed: 20th October 2017).

9. SputnikNews. (2017) Kto yedet obuchat' tadzhikskikh detey: znakomstvo s uchitelyami iz regionov $R F$ [Who goes to teach Tajik children: Meet teachers from Russian regions]. [Online] Available from: http://sptnkne.ws/fWP8. (Accessed: 25th October 2017).

10. Ministry of Education and Science of the Russian Federation. (2014) Departament strategii, analiza i prognoza [Department of Strategy, Analysis and Forecast]. [Online] Available from: http://minobrnauki.rf/ministerstvo/sta-tistika/informatsiya-2014. (Accessed: 3rd January 2016).

11. MGU Russian Language Centre. (n.d.) Onlayn test po russkomu yazyku kak inostrannomu [Online test in Russian as a foreign language]. [Online] Available from: https://mgurussian.com/ru/learn/test-online/. (Accessed: 23rd October 2017).

12. POVT-2. Author's Archive.

13. Sputnik. (2017) Prints Aga-Khan IV vstretilsya s glavoy MID Rossii Sergeyem Lavrovym [Prince Aga Khan IV meets with Russian Foreign Minister Sergei Lavrov]. [Online] Available from: http://ru.sputnik-tj.com/russia/20170420/1022111837/aga-khan-IV-vstretilsya-s-sergeyemlavrovym.html. (Accessed: 20th November 2017).

14. Regnum News Agency. (2017) Rossiya uvelichila kolichestvo kvot dlya tadzhikskikh studentov [Russia increased the number of quotas for Tajik students]. 7th February. [Online] Available from: https://regnum.ru/news/2236010.html. (Accessed: 10th November 2017).

15. SPKU-1. Author's Archive. 
16. STT-6. Author's Archive.

17. STT-10. Author's Archive.

18. STT-15. Author's Archive.

19. STT-16. Author's Archive.

20. TDKr-1. Author's Archive.

21. TDT-6. Author's Archive.

22. Official Website of Tomsk Region Administration. (2017) Tomskiy gubernator i genkonsul Tadzhikistana obsudili sotrudnichestvo regiona s respublikoy [Tomsk Governor and Consul General of Tajikistan discussed the cooperation of the region]. [Online] Available from: https://www.tomsk.gov.ru/news/front/view/id/23432. (Accessed: 25th November 2017). 